Review article

\title{
Wastewater from Washed Rice Water as Plant Nutrient Source: Current Understanding and Knowledge Gaps
}

\author{
Nabayi Abba ${ }^{1,2}$, Christopher Teh Boon Sung ${ }^{1 *}$, Tan Ngai Paing ${ }^{1}$ and \\ Ali Tan Kee Zuan ${ }^{1}$ \\ ${ }^{1}$ Department of Land Management, Faculty of Agriculture, Universiti Putra Malaysia, 43400 UPM, Serdang, \\ Selangor, Malaysia \\ ${ }^{2}$ Department of Soil Science, Faculty of Agriculture, Federal University Dutse, Nigeria. PMB 7156, Ibrahim \\ Aliyu bye-pass Jigawa state, Nigeria
}

\begin{abstract}
A significant wastewater source in every household is washed rice water (WRW) because it contains leached nutrients (from washing the rice prior to cooking) that could be used as fertilizer. The paper reviewed the current understanding of the potential use of WRW as a plant nutrient source. WRW was shown to increase vegetables growth, such as water spinach, pak choy, lettuce, mustard, tomato, and eggplant. Different researchers have used various amounts of WRW, and their results followed a similar trend: the higher the amount of WRW, the higher the plant growth. WRW has also been used for other purposes, such as a source of carbon for microbial growth. WRW from brown rice and white rice had nutrients ranging from 40-150, 43-16306, 51-200, 8-3574, 36-1425, 27-212, and 32-560 $\mathrm{mg} \mathrm{L}^{-1}$ of N, $\mathrm{P}, \mathrm{K}, \mathrm{Ca}, \mathrm{Mg}, \mathrm{S}$, and vitamin B1 (thiamine), respectively. Proper utilization of WRW could reduce chemical fertilizer use and prevent both surface and groundwater contamination and environmental pollution. However, only a few of the studies have compared the use of WRW with the use of conventional NPK

ARTICLE INFO

Article history:

Received: 05 December 2020

Accepted: 15 April 2021

Published: 31 July 2021

DOI: https://doi.org/10.47836/pjst.29.3.11

$\overline{\text { E-mail addresses: }}$

abba.nabayi@fud.edu.ng (Nabayi Abba)

chris@upm.edu.my (Christopher Teh Boon Sung) ngaipaing@upm.edu.my (Tan Ngai Paing)

tkz@upm.edu.my (Ali Tan Kee Zuan)

* Corresponding author fertilizer. The major drawback of WRW studies is that they lack depth and scope, such as determining the initial and (or) final soil physico-chemical properties or plant nutrient contents. Considering the rich nutrient content in WRW, it will impact plant growth and soil fertility when used as both irrigation water and plant nutrient source.
\end{abstract}


Therefore, it is recommended that studies on WRW effect on soil microbial population, plant, and soil nutrient contents to be carried out to ascertain the sustainability of WRW use as a plant nutrient source.

Keywords: Irrigation, liquid fertilizer, plant growth, soil microbes, wastewater

\section{INTRODUCTION}

Washed rice water (WRW) refers to the water used in washing rice before the rice is cooked. Milled rice is washed prior to cooking to remove the bran, dust, and dirt from the rice (Juliano, 1993). But rice washing can remove a significant amount of water-soluble nutrients from the rice. Several studies as reviewed by Juliano (1985) have shown that rice washing can lose up to $7 \%$ protein, $65 \%$ crude fat, 30\% crude fiber, $59 \%$ thiamine, $26 \%$ riboflavin, $60 \%$ niacin, $26 \% \mathrm{Ca}, 47 \% \mathrm{P}, 47 \% \mathrm{Fe}, 11 \% \mathrm{Zn}, 70 \% \mathrm{Mg}$, and $41 \% \mathrm{~K}$ via leaching from the rice. Although these losses mean fewer nutrients are available in the rice for human consumption, they also mean the WRW, now enriched by these leached nutrients, could be used as a liquid plant fertilizer and soil amendment. There are many claims on the beneficial effects of WRW as a plant fertilizer, but these claims are very often anecdotal, given without any support of strong scientific evidence.

Unfortunately, rigorous, and in-depth scientific studies on the specific use of WRW as a plant fertilizer are very scarce. Instead, the research focus and interests on WRW are mostly on its potential use for either human or animal health (e.g., use of washed rice water as a health supplement or medical treatment) or cosmetology purposes (e.g., use of washed rice water as a human facial, skin, and hair care). From our search of the literature, most of the research on the potential use of WRW for agriculture purposes appears to be done in Indonesia. Moreover, these studies are often reported in non-English (though some of these reports include abstracts in English). These reports are also not easily available, and they are mostly published in non-cited journals.

But why use WRW when there are conventional fertilizers available? Reusing washed rice water ought to be encouraged because its practice is a part of better water governance. Global freshwater demand is expected to increase by 55\% by 2050 (Park, 2013). This increase is mainly due to detrimental climate change and increasing world population, driving the United Nation to advocate for more effective water governance. Wastewater, rather than just being discarded into the environment, is instead reused, treated, or recycled. The AQUASTAT database of the Food and Agriculture Organization of the United Nations (FAO) estimates more than half of the global freshwater withdrawals are simply discarded as wastewater into the environment (WWDR, 2016). Municipal water demand corresponds to $11 \%$ of the global freshwater withdrawal, but out of this, only $3 \%$ is consumed, with the remaining $8 \%$ simply discarded, unused, as wastewater. Used water is being generated by towns and cities, from domestic purposes. These activities represent a waste product 
that must be utilized downstream as a resource or otherwise safely disposed. The average volume of wastewater generated daily by human activities depends on the water availability in the house, cultural type, cost of water, and socioeconomic conditions (Kalavrouziotis, 2015). "United Nations Agenda for Sustainable Development 2030" additionally aims to manage and reduce the release of wastes and chemicals into the environment (FAO, 2015).

Amoro et al. (2019) stated that the increase in water scarcity has increased the interest in finding various ways for wastewater reuse. Recently, there is an increase interest in wastewater utilization for irrigation (Khalid et al., 2018). Water scarcity, together with soil erosion, land degradation, and climate change, are the main threats to crop productivity (Roy et al., 2011). The most significant contribution of wastewater reuse in agriculture is to reduce the pressure on freshwater sources (Jaramillo \& Restrepo, 2017; Winpenny et al., 2013). The greatest global water user is agriculture, which consumes $70 \%$ of available water (Pimentel \& Pimentel, 2007). Thus, wastewater reuse contributes to food safety; thereby, increasing agricultural production in regions experiencing water shortages (Corcoran et al., 2010). The reasons for wastewater reuse are two-fold: water for the ever-increasing world population and for agriculture activities (Pescod, 1992), which make it necessary and worth to initiate and support wastewater reuse projects all over the world (Kretschmer et al., 2002). Kretschmer et al. (2002) for instance, reported that wastewater has the potential in improving soil properties and increasing plant yield.

The use of wastewater has been reported to save 45 to $94 \%$ of fertilizer needed in alfalfa and wheat production (Balkhair et al., 2013). The effects of wastewater application on the soil nutrient status and nutrient use efficiency are also reported in crop production. It was observed that the yield of marketable fruit was higher with wastewater compared to the use of groundwater (Gatta et al., 2015a; Gatta et al., 2015b). Some other studies (Aghtape et al., 2011; Cirelli et al., 2012; Li \& Li, 2009) have also indicated the efficacy and superiority of wastewater irrigation which could be attributed to their enriched nutrients content. The wastewater application on soil also affects the soil microbial activity either directly or indirectly by changing the soil physicochemical properties (Ibekwe et al., 2018; Oliveira \& Pampulha, 2006).

Considering that rice is the second most widely grown cereal, and it is eaten by nearly half of the world's population (GRiSP, 2013), the practice of reusing WRW can potentially lead to considerable savings in water as well as fertilizer use. Consequently, less dependence on energy in today's environment of detrimental climate change. The use of biofertilizers is, therefore, a part of sustainable agriculture that was proposed to reduce the use of chemical fertilizers (Sairi et al., 2018).

This review has found only 41 papers or studies that specifically used WRW as a plant fertilizer or soil amendment. But only about $10 \%$ of these papers were published in indexed journals, and the others: $61 \%$ in non-indexed journals and $29 \%$ in student research reports. This breakdown of papers indicates a lack of in-depth study on the potential use 
of WRW. The objective of the paper was to review these studies to determine our current understanding on WRW and its potential use as organic liquid plant fertilizer, identify the knowledge gaps, and finally recommend future research.

\section{RICE TYPES}

There are many rice forms, such as rough rice, brown rice, parboiled rice, regular milled white rice, pre-cooked rice, quick-frozen rice, and crisped, puffed or expanded rice (Kanchanawongkul, 2004). The mineral composition of rice differs according to rice variety, rice fertilization and cultivation, rice processing and cooking, and the soil type on which the rice is grown (Abbas et al., 2011; Roy et al., 2011). The parboiling in rice processing helps to retain some of the nutrients, where milling losses and rice recovery (whole rice kernels after milling) are energy-and labor-intensive activities (Roy et al., 2011). Brown rice is unmilled rice with its bran still intact. It is whole grain rice with an intact bran layer having its inedible outer hull removed (Upadhyay \& Karn, 2018). Many researchers have reported that brown rice has a higher nutrients content than white rice (Babu et al., 2009; Pascual et al., 2013). Essential nutrients like iron, manganese, phosphorus, zinc, thiamine, niacin, vitamin E, dietary fiber, protein, and carbohydrate are higher due to the presence of an unremoved bran layer (Babu et al., 2009; Pascual et al., 2013). Red rice is considered as a weed in many countries, such as Greece, Latin America, Spain, and other temperate regions where this rice is grown with white rice (Patindol et al., 2006). However, in some countries, such as Sri Lanka and the Philippines, red rice is grown as a staple rice cultivar (Itani \& Ogawa, 2004). Red rice is gaining popularity in Japan as a functional food because of its high polyphenols and anthocyanin content (Itani \& Ogawa, 2004; Ling et al., 2001). White rice is known to have a higher glycemic index than other types of staple foods such as brown rice, whole grain, and barley (Helmyati et al., 2020). Black rice is one of the new rice that has a lower patronization rate (Helmyati et al., 2020). Together with brown rice, black rice is higher in fiber and antioxidants than white rice (Hernawan \& Meylani, 2016).

\section{WASHED RICE WATER AND WATER GOVERNANCE}

Agricultural wastes are abundant in every country, with over 2 billion tons of household wastes generated globally, with more than 60 tons every second in the year 2020 (World Count, 2020). Malaysia produces about 2.6 million tons of agricultural wastes per year (Sreenivasan et al., 2012). It is estimated that about 3 million tonnes of rice are consumed yearly by Malaysians (Bee, 2019). As a conservative estimate, this works out to at least 3 billion L of WRW produced per year by Malaysians, and this amount is unused and simply discarded. So, it would be beneficial if these wastes could instead be utilized to reduce environmental pollution and to increase soil fertility. Different authors have reported an increase in total organic carbon (TOC) and nitrogen due to irrigation using wastewater, 
depending on the amount of organic matter in the wastewater (Jaramillo \& Restrepo, 2017; Sun et al., 2014).

The indiscriminate disposal of WRW is harmful to the environment (e.g., via $\mathrm{N}$ and P pollution) (Siagian, 2018). Based on the reported nutrient content of the WRW in Table 1 , it is evident that it is a potential source of contamination of our water sources (He et al., 2016b). Suryana et al. (2017) classified WRW as a waste considered insignificant or unimportant by the Indonesian public. The growing concern about the negative impacts of urban wastewater on the environment to reduce pollution has forced researchers to look for new and effective recycling alternatives (Santos et al., 2017). WRW from the household can serve as organic fertilizer for plant use (Iskarlia, 2017); besides, it can improve and increase soil fertility (Supraptiningsih et al., 2019) and use as an amendment (Brown et al., 2011; Cogger, 2005; Lehmann, 2011).

Many places around the world discharge domestic wastewater into natural waters. Zou et al. (2012) reported about $96 \%$ of villages in China would simply discard domestic wastewater, which have contaminated natural water bodies. Winance et al. (2018) reported production of $4 \mathrm{~L}$ of WRW by every household in Baomekot Village being thrown every day as waste, which can be utilized as irrigation water. Consequently, a few WRW reuse communal programs have been established, such as in Lambangkuning Village, Indonesia (Supraptiningsih et al., 2019). This village comprised about 30 households, and each of them produced about $5 \mathrm{~L}$ of WRW every day, making $150 \mathrm{~L}$ per day. The WRW is collected from every household, pooled, and used to irrigate the garden crops in the village and homes. Another communal WRW program is in Polo Geulis, a village in Central Bogor, Indonesia, which practices a centralized water-saving system. WRW is collected from the town citizens, after which the water is used to irrigate and fertilize their neighborhood crops of herbs and vegetables (The Jakarta Post, 2017).

\section{Washed Rice Water as Fertilizer}

The global mineral fertilizer demand increases every year because its demand is affected by population and economic growth, agriculture production and governance, and food price (FAO, 2015). Compared with mineral fertilizers, organic fertilizer has a longer-term effect on soils and plants, and it is claimed to be more environmentally friendly (Chandini et al., 2019; Sairi et al., 2018; Shaviv, 2001). However, one of the shortcomings of organic fertilizer is its slower effect on plants than inorganic fertilizers due to the slower release of organic fertilizers' nutrients. Among the organic fertilizers, liquid organic fertilizer is regarded to be better as the nutrients are applied in liquid soluble forms that can easily be absorbed by plants (Duaja et al., 2012). However, the nutrients release rates must match the plant nutrient uptake; otherwise, these nutrients, if not retained in the soils, may be lost via leaching. 
Recent researches have shown that WRW can be used as a plant nutrient source as indicated by Bahar (2016), Wardiah and Hafnati (2014), Suryana et al. (2017), Hairudin (2015), Fitriani (2019), Hariyadi (2020), Handiyanto et al. (2013) and Leandro (2009). The presence of carbohydrates, proteins, vitamins, and other minerals at different concentrations in the WRW (Juliano, 1985; Purnami et al., 2014), depends on several factors, such as the rice variety, rice sources, and rice washing intensity (Akib et al., 2015; Purba et al., 2015; Purnami et al., 2014). Gibberellin and auxin are the two most common hormones employed in stimulating plant growth and both are reported to be present in WRW by Leandro (2009). Andrianto (2007) also attributed the increase in Adenium's plant roots to the presence of vitamin B1 in the WRW, which stimulated the plant growth into having greater root biomass. Vitamin B1 (Thiamine) applied once every two days combined with $\mathrm{KNO}_{3}$ fertilizer increased the vegetative growth of Dendrobium sp. (orchid) seedlings (Sianipar, 2004).

The use of WRW as a plant nutrient source could reduce chemical fertilizer procurement and pollution. Kalsum et al. (2011) reported that fermented WRW contains numerous nutrients that are essential to plant growth and development. Carbohydrate is the most abundant content in WRW, by up to $300 \mathrm{mg} \mathrm{L}^{-1}$ (Kalsum et al., 2011; Nurhasanah et al., 2010). Dini and Salbiah (2019) found WRW have nutrient contents large enough to increase the vegetative and physiological growth of pepper after being fermented with cellulolytic bacteria. Generally, the efficiency of wastewater as a crop nutrient source largely depends on the soil fertility level, type and nutrient requirement of the crop, and the nutrients in the wastewater. The nutrient use efficiency for wastewater is high (Khalid et al., 2018). This is because the nutrients present in wastewater are commonly found in a dissolved form and, therefore, they are readily available for plant uptake (Khalid et al., 2017). Moreover, the wastewater-induced nutrient supply matches the demand of crops because nutrients are supplied with each irrigation, compared to synthetic fertilizers usually applied to crops in splits (Khalid et al., 2017; Sadaf et al., 2017).

An evaluation of WRW on the growth of both tomato and eggplant at different concentrations of the WRW gave a significant higher yield of their test crops such as in plant height, leaf number, and fresh plant weight (Istiqomah, 2012; Ariwibowo, 2012). Likewise, Karlina et al. (2013) compared the growth of spinach using different organic fertilizers and found WRW treatment to have a significant higher plant height than others. Consequently, they attributed the higher growth and yield to the higher nutrient contents of the WRW as well as the presence of a plant growth hormone (auxin).

However, WRW studies are often plagued by common inadequacies such as the absence of an initial and final soil analysis (e.g., Hairudin, 2015; Hariyadi, 2020) and lack of detailed description of the WRW application timings and methodology of the WRW preparation (e.g., Handiyanto et al., 2013; Hikmah, 2015), soil physicochemical and 
microbial properties, and the application area (e.g., Ariwibowo, 2012; Fitriani, 2019), as well as lack of comparisons between WRW treatments with conventional fertilizers such as NPK (e.g., Bahar, 2016; Dini \& Salbiah, 2019; Ginting et al., 2017; Wulandari et al., 2012).

\section{Washed Rice Water as a Potential Environmental Pollutant}

Urban runoff and stormwater can, in some instances, find their way into sewage works (Duncomb et al., 1982). Industrial contamination is a major problem with sewage sludge; however, domestic sewage is also a potential significant contaminant (Naidu et al., 2004). Lack of such wastewater utilization practices will have adverse effects on nearby freshwater ecosystems and groundwater (He et al., 2016b). Moreover, biochemical oxygen demand (BOD) is high in WRW (2715 to $3800 \mathrm{mg} \mathrm{L}^{-1}$ ) produced from industrial rice washing before use in food processing (He et al., 2016a). Starch, proteins (mainly composed of glutelin), and vitamins are the main solid particles composition of WRW (Watanabe et al., 2013). Malaysian soils are typically low in soil organic matter and have low cation exchange capacity (Shamshuddin, 1989). Consequently, the country's soils have inherently weak retention of nutrients that could increase the risk of large losses of nutrients via leaching. Leaching is a serious problem because large amounts of nutrients being leached out from the soil could pollute the groundwater and other water sources. The nutrient analyses of WRW show that it could be of greater concern due to its $\mathrm{P}$ and $\mathrm{N}$ content that can cause eutrophication and groundwater contamination, respectively (Table 1), upon their accumulation. The primary causes of groundwater contamination by nitrogenous compounds are landfill leachates (Nooten et al., 2008) and nitrogen-based fertilizer used in agriculture and uncontrolled wastewater discharge (Ghafari et al., 2008).

The treatment of wastewater generally requires a sewage system and a costly wastewater treatment plant (Kretschmer et al., 2002). One reason for this is it requires constant supply of power that may not always be available in some countries (Kretschmer et al., 2002). He et al. (2016a) reported that WRW have $\mathrm{NO}_{3}^{-}, \mathrm{NO}_{2}^{-}, \mathrm{NH}_{4}^{+}$, total $\mathrm{N}$, and total $\mathrm{P}$ in the range of 4.19 to $10.14,0$ to $0.08,2.57$ to $39.72,51.26$ to 84.79 , and 23.41 to $58.12 \mathrm{mg} \mathrm{L}^{-1}$, respectively. He et al. (2019) further used WRW for denitrification as a source of carbon for the microorganisms, which has a $\mathrm{NO}_{3}^{-}, \mathrm{NO}_{2}^{-}, \mathrm{NH}_{4}^{+}$, total $\mathrm{N}$, total $\mathrm{P}$, and total organic carbon $0.63,0.04,0.17,66.82,33.96$ and $495 \mathrm{mg} \mathrm{L}^{-1}$, respectively. The presence of ammonia might be due to the degradation of WRW by microbes as stated by He et al. (2019). Deepa et al. (2008) reported that rice grains contain 7.95-9.52 $\mathrm{g}$ of protein

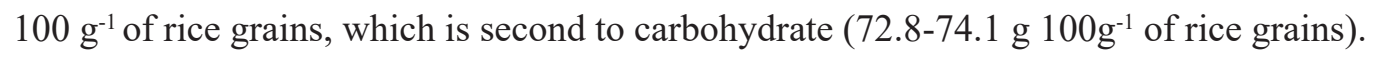
The analyses by Deepa et al. (2008) indicated WRW could have a significant amount of protein, and the protein degradation would produce ammonium via ammonification (Jones \& Kielland, 2012). 
Nabayi Abba, Christopher Teh Boon Sung, Tan Ngai Paing and Ali Tan Kee Zuan

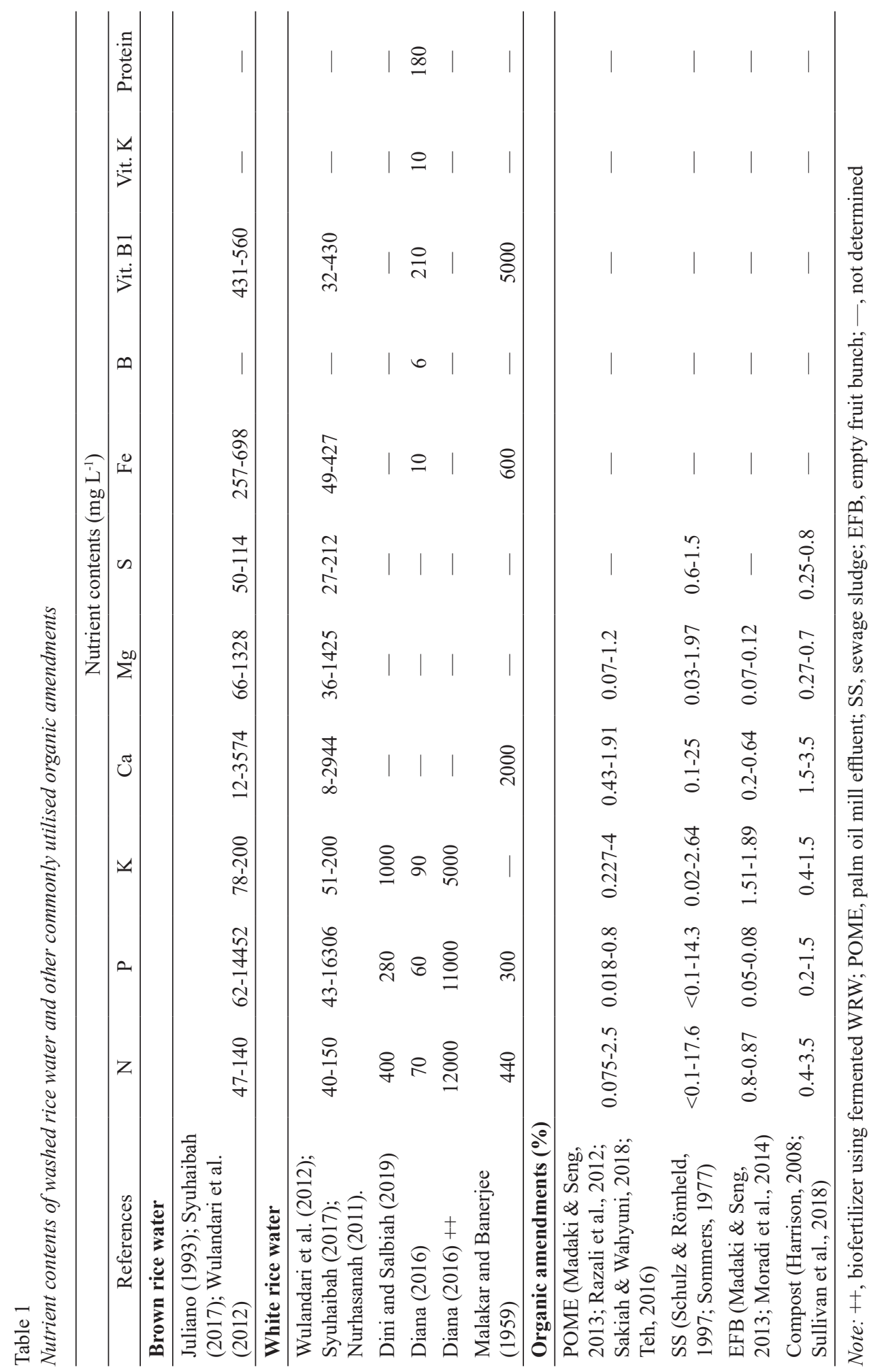




\section{Washed Rice Water Nutrient Contents and its Effect on Plant Growth}

Researchers have tested WRW on several crops which is shown in Table 2. They found that WRW increased the plant height, stem diameter, and yield of several crops such as: tomato (Ariwibowo, 2012; Hariyadi, 2020; Istiqomah, 2012; Leandro, 2009), water spinach (Bahar, 2016; Karlina et al., 2013; Syuhaibah, 2017), eggplant (Bukhari, 2013; Yulianingsih, 2017), and pak choy (Wardiah \& Hafnati, 2014). WRW was also reported to have increased the lettuce yield and root weight (Siagian, 2018; Wulandari et al., 2012). It also increased the growth of mushroom (Handiyanto et al., 2013; Kalsum et al., 2011), height and leaf number of Adenium plant (Andrianto, 2007), chili (Sairi et al., 2018), as well as mustard green plants (Hairudin, 2015).

Wulandari et al. (2012) attributed the higher root growth of lettuce to the high sulfur (S) content $\left(270 \mathrm{mg} \mathrm{L}^{-1}\right)$ present in the WRW (Table 2), in which S helps in thiamine synthesis. Thiamine (Vitamin B1) is an essential component of plant stress responses, disease resistance, crop yield, and several non-coenzyme roles of this vitamin are being characterized (Fitzpatrick \& Chapman, 2020). As shown in Table 1, when WRW is compared with organic material (OM), particularly liquid OM, WRW is a good plant nutrient source. However, despite lower nutrient contents than compost and sewage sludge, it is at par with EFB and POME for $\mathrm{N}, \mathrm{P}, \mathrm{Ca}$, and $\mathrm{Mg}$ nutrients. This indicated that WRW could make a significant impact when simultaneously used as irrigation water and plant nutrient source (Kalsum et al., 2011; Karlina et al., 2013; Lestari, 2010; Nurhasanah, 2011; Wardiah \& Hafnati, 2014).

WRW will ferment over time. The maximum fermentation time tested was 6 days (Akib et al., 2015), where the fermented WRW was found to produce higher ethanol, phosphorus, nitrogen, and sulfur. Dini and Salbiah (2019) reported the nutrient contents of WRW fermented with a cellulolytic bacterial consortium to be 400, 280, and $1000 \mathrm{mg} \mathrm{L}^{-1}$ of N, P, and K, respectively. The relatively higher amount of N, P, and K, as compared with Wulandari et al. (2012), Syuhaibah (2017), and Nurhasanah (2011), could be attributed to the presence of the bacteria in the work by Dini and Salbiah (2019). Likewise, presence of bacteria capable of fixing atmospheric $\mathrm{N}$ and $\mathrm{P}, \mathrm{K}$ solubilization could be why it has higher $\mathrm{N}$ and $\mathrm{P}$ (Table 1) as compared to the domestic waste used by Vermaat and Hanif (1998). Compared with the general nutrients content of other soil amendments such as EFB and compost (Table 1), WRW is a compatible plant nutrient supplement with the others. The commonly used soil amendments are compost and peat moss (Harrison, 2008; Sullivan et al., 2018), which compared with WRW, have higher N content by dry weight (3-1\%), but have lower plant available $\mathrm{N}$ forms of 0.05 nitrates and $0.01 \%$ ammonium (Harrison, 2008).

Diana (2016) recorded high N (1.2\%) content in fermented WRW (fermented with sugar and milk) for the development of biofertilizer (Table 1). Significant variability exists more in the $\mathrm{N}$ content in the WRW, with some authors reporting as high as $1.2 \%$ (Diana, 
Nabayi Abba, Christopher Teh Boon Sung, Tan Ngai Paing and Ali Tan Kee Zuan

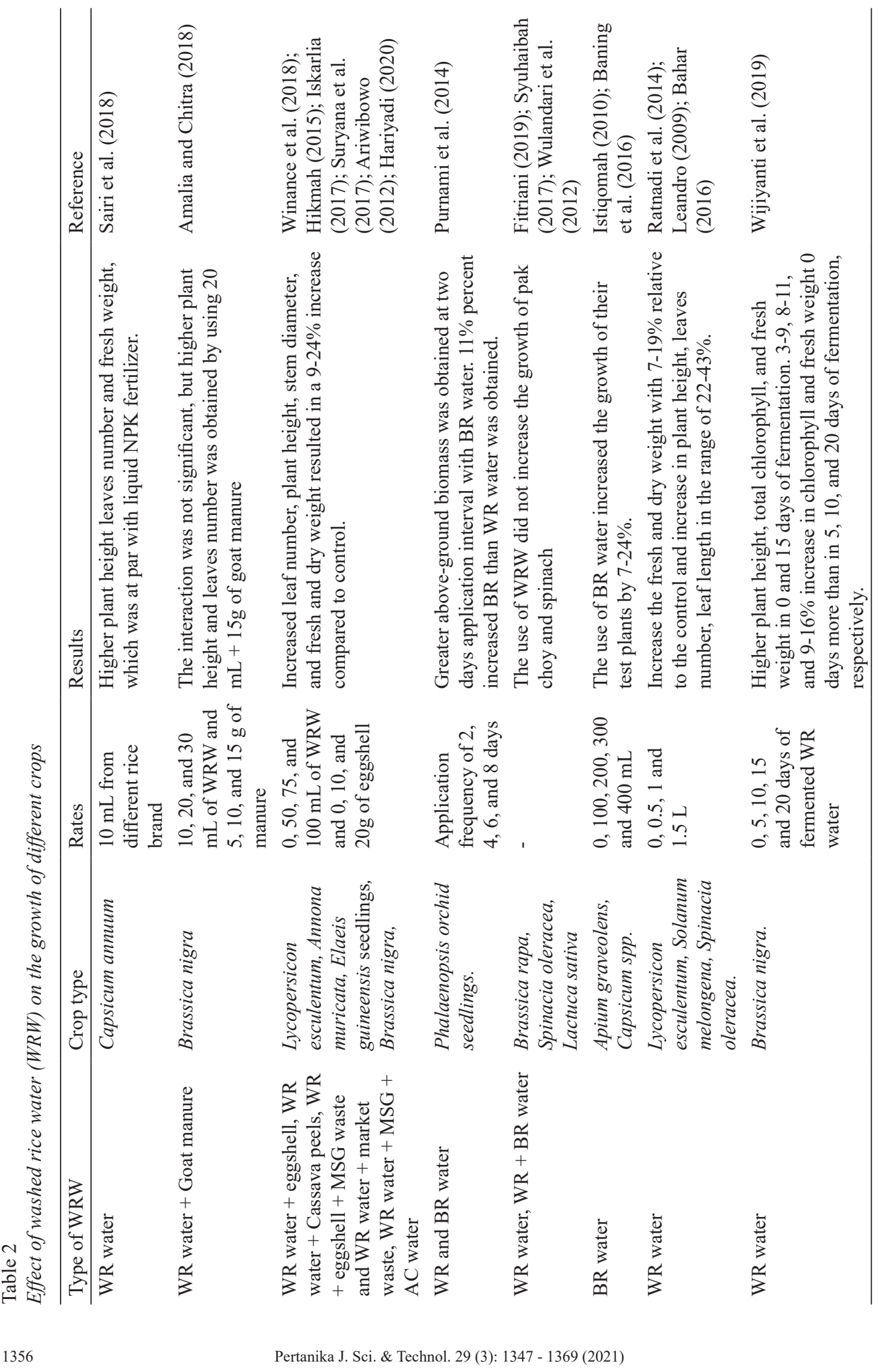


Wastewater from Washed Rice Water as Plant Nutrient Source

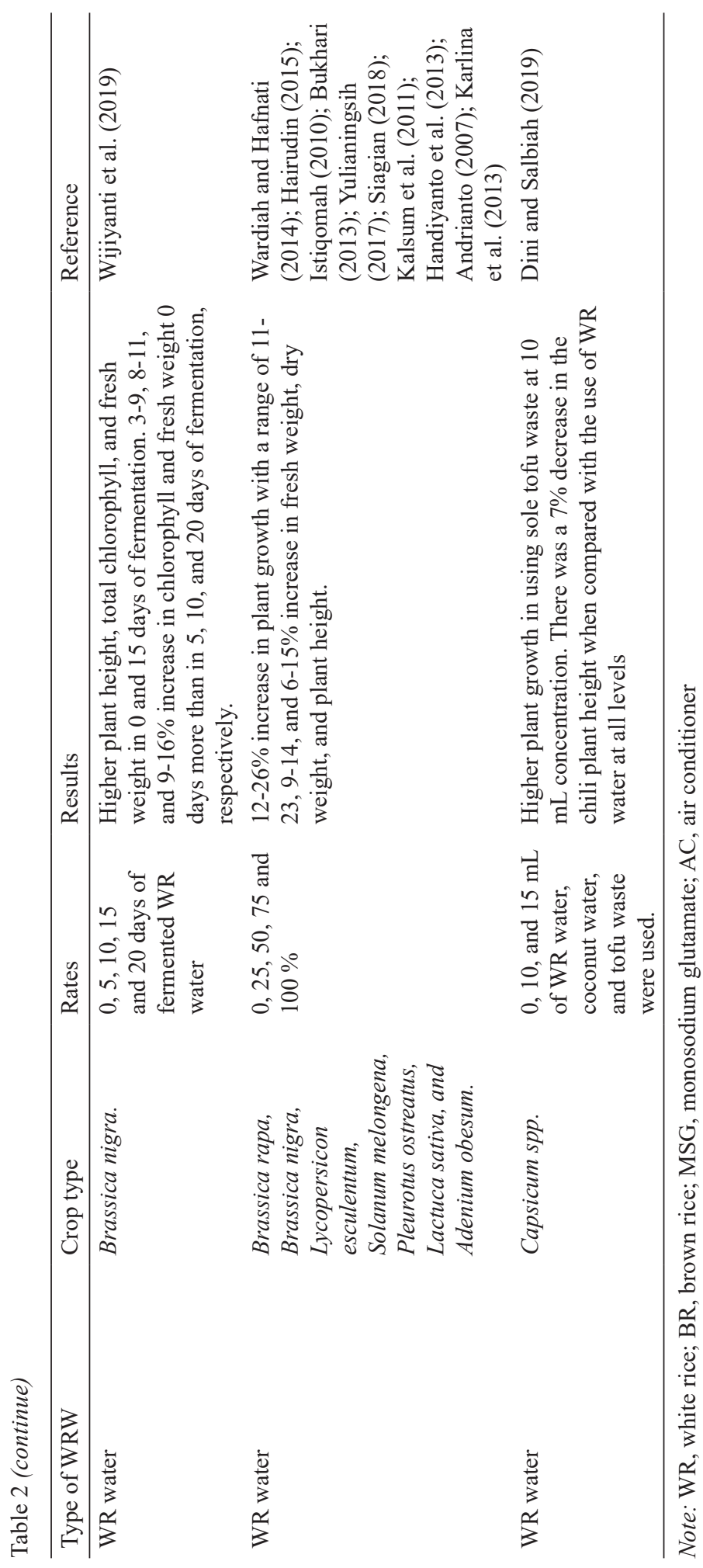


2016) while others far below $0.01 \%$ (Wulandari et al., 2012). These differences could be associated with the inadvertent fermentation of the WRW or differences in the rice washing intensity. When WRW is fermented, the complex compounds are broken down, which could lead to greater nutrient content. Wastewater irrigation in soil altered the ammonia-oxidizing bacterial population making the Nitrosospira and Nitrosomonas species dominant (Mechri et al., 2008). It is reported that wastewater containing an average concentration of $35 \mathrm{mg}$ $\mathrm{L}^{-1}$ of $\mathrm{N}, 10 \mathrm{mg} \mathrm{L}^{-1}$ of $\mathrm{P}$, and $30 \mathrm{mg} \mathrm{L}^{-1}$ of $\mathrm{K}$, mostly meets many crops' requirements, particularly vegetables (Kalavrouziotis, 2015). Overall, the results showed that the nutrient content, particularly N, P, and K (Table 1), are within the range expected to impact plant growth and development by Kalavrouziotis (2015).

WRW can either be applied on a sole basis or in combination with other organic wastes with irrigation water. When applied with other organic wastes WRW generally showed significantly higher crop yields, particularly at higher WRW application rates (Table 2). Sairi et al. (2018) used NPK in the growth of chili seedlings and found it to be on par with fermented WRW, which led them to conclude that fermented WRW can be used as NPK replacement. Hariyadi (2020) substantiated it with a recent study that reported that WRW performed better than monosodium glutamate and air conditioner's water on tomato's growth (Table 2).

\section{Comparison between White and Brown Rice Washed Water on Plant Growth}

Few studies compared WRW from white (WR) and brown rice (BR) on plant growth. Wulandari et al. (2012) reported WRW from both BR and BR had non-significantly increased the fresh and dry weight of lettuce as compared with just using tap water. Between the two types of WRW, WR water improved the fresh weight of the crop more significantly at an early stage, but at harvest, there was no significant difference than the BR water-treated plants. When WR and BR water were compared with tap water (control), higher roots dry weight was recorded in both WR and BR water, which differed significantly from control. Wulandari et al. (2012) and Syuhaibah (2017) reported no overall significant difference between WRW and tap water in lettuce and spinach growth, respectively (Table 2).

Purnami et al. (2014) evaluated the use of WR and BR water on the growth of Phalaenopsis orchid nursery and found the use of BR water once every four days increased the total fresh weight, root length, plant height and higher above-grown biomass more than the WR water. Fitriani (2019) studied the effect of different sources of WRW on the growth of pak choy at different concentrations but found no significant difference between the WRW types on the growth of the plant. This indicates that the WRW had met the nutrients requirement of pak choy enough to support its metabolism and growth. Istiqomah (2010) stated that BR washed water had a significant effect on the increase in plant height and number of leaves of celery plants. The results of Baning et al. (2016) showed the effect of 
BR water at different concentrations on the growth of pepper plants and found to increase the number of leaves, fresh and dry weight and recommended its use on the growth of pepper (Table 2).

\section{Effect of WRW on Microbial Growth}

Juwarkar et al. (1988) found populations of soil bacteria, fungi, and actinomycetes increased with increasing domestic wastewater applications. An increase in Azotobacter soil population was also observed due to the wastewater application (Juwarkar et al., 1988). Other than for fertilizer, WRW has also been studied for its potential use as a growth media for the bacteria Bacillus thuringiensis (Blondine \& Yuniarti, 2008) and an alternative media carrier for Pseudomonas fluorescence. These bacteria help to control rust disease and to stimulate the growth of plants (Nurhasanah et al., 2010). Fermentation of WRW can be aided using microorganisms such as Rhizopus, Aspergillus., Mucor, Amylomyces., Endomycopsis, Saccharomyces, Pichia anomala, Lactobacillus, and Acetobacter (Akib et al., 2015). The fermentation process helps break down the complex structure of carbohydrates into other simpler compounds such as bioethanol and other elemental forms of the compound that could easily be used by the plants. WRW can support the growth of useful microorganisms (bacteria) such as Rhizobium, Azospirillum, Azotobacter, Pseudomonas, Bacillus for plant growth, and soil fertility increased (Akib et al., 2015). Amalia and Chitra (2018) reported the presence of Pseudomonas fluorescence bacteria among other microorganisms in WRW. It is a potential biocontrol agent that adapts well to plant roots and can help plants fight against pathogens or be resistant to disease (Hoffland et al., 1996). Furthermore, the bacteria mentioned above can produce phytohormones, which stimulate growth and increases cell enlargement. These microbes play a role in controlling pathogens that cause rust and triggering the plant growth to be more effective (Hairudin, 2015). Sairi et al. (2018) reported that Bacillus spp. and Lactobacillus spp. to be the common genus in WRW upon fermentation. Ahemad and Kibret (2014) reported using both genera to increase plant growth either as biofertilizer or as a biocontrol agent against plant disease. However, WRW not only supports the growth of bacteria but also several fungi species, such as Trichoderma. Penicillium and Saccharomyces, found upon fermentation for seven days, these fungi are beneficial to plant growth (Sairi et al., 2018). WRW has also been used as growth media for lactic acid bacteria (Watanabe et al., 2011; Watanabe et al., 2009).

\section{LIMITATIONS}

To our knowledge, this paper is the first review the specific use of WRW as a plant fertilizer. Most of the prior studies on WRW were done at the diploma and undergraduate level, which together with non-peer reviewed journals, made up 90\% WRW studies. Only 10\% of the 41 WRW studies were published in peer-reviewed journals. For this review, the 
use of students' reports and non-indexed journals were inevitable because of the lack of literature on the WRW use as a plant fertilizer. This indicates a knowledge gap in WRW reuse in agriculture.

Most WRW studies did not report the application frequency of the WRW, how WRW was applied, or even the area of the field or plot used. Furthermore, most of the WRW studies did not carry out the chemical analyses on the WRW used; neither did they analyze the initial and final plant and soil nutrient content. Consequently, it is unknown if, or by how much, the WRW had increased the nutrient content of the various test crops and soils due to WRW application alone. The effect of WRW on many basic soil physicochemical properties was also not measured. All their studies were focused only on a limited number of plant growth parameters. WRW studies that did WRW nutrient analyses examined only the macronutrients $(\mathrm{N}, \mathrm{P}, \mathrm{K})$, none on the micronutrient contents, with few comparisons with NPK mineral fertilizer. WRW studies so far have all been to examine WRW effects over a short-term period (e.g., one planting cycle). But WRW may have a long-term impact on the soil nutrients as well as the soil microbial population. Although many research papers on WRW lack scientific robustness, they remain useful because their findings, at best, suggest that WRW can be beneficial to plant growth and yield as well as increase beneficial soil bacteria for soil health.

\section{CONCLUSIONS AND RECOMMENDATIONS}

WRW contains nutrients that could supplement conventional fertilizers (Table 1). It was reported to increase the growth of many crops ranging from the above to below-ground biomass (Table 2). Furthermore, it has also been used in combination with other wastes and was observed to increase plant growth. Various rates of the WRW have been used, with no reported negative effects even at high WRW rates. WRW appears suitable as a supplemental organic fertilizer to other organic and chemical fertilizers. Thus far, the severe limitation on WRW research is the lack of scientific rigor, lack of research methodology description, and, most importantly, the bulk of the study was published in non-indexed reports. Therefore, the results from these researches are at best tentative.

The following is recommended for a detailed evaluation of WRW as organic fertilizer, soil amendment, and source of soil microbial population increase:

1. Soils should be subjected to initial and final physicochemical and nutrient analyses to ascertain how the use of the WRW would alter the soils.

2. Soil microbial study should be incorporated in the study of WRW, particularly the soil microbial population, as WRW contains minerals and compounds essential for their growth and multiplication.

3. Long-term studies over several planting cycles on WRW should be conducted. 
4. Periodic soil nutrient content and microbial population should be carried out to ascertain the temporal effect of WRW, particularly over prolonged periods.

5. The use of WRW should be compared with the use of conventional mineral fertilizer and other organic soil amendments (such as composts and palm oil mill effluent).

\section{ACKNOWLEDGEMENT}

The helpful assistance from the laboratory staff of Faculty of Agriculture, Uni. Putra Malaysia is acknowledged.

\section{REFERENCES}

Abbas, A., Murtaza, S., Aslam, F., Khawar, A., Rafique, S., \& Naheed, S. (2011). Effect of processing on nutritional value of rice (Oryza sativa). World Journal of Medical Sciences, 6(2), 68-73.

Aghtape, A. A., Ghanbari, A., Sirousmehr, A., Siahsar, B., Asgharipour, M., \& Tavssoli, A. (2011). Effect of irrigation with wastewater and foliar fertilizer application on some forage characteristics of foxtail millet (Setaria italica). International Journal of Plant Physiology and Biochemistry, 3(3), 34-42.

Ahemad, M., \& Kibret, M. (2014). Mechanisms and applications of plant growth promoting rhizobacteria: Current perspective. Journal of King saud University-science, 26(1), 1-20. http://dx.doi.org/10.1016/j. jksus.2013.05.001

Akib, M. A., Setiawaty, H., Haniarti, H., \& Sulfiah, S. (2015). Improving the quality of "Leri” rice washing waste by different period of fermentation and yeast concentration as an alternative liquid organic fertilizer. International Journal of Agriculture System, 2(2), 153-162. http://dx.doi.org/10.20956/ijas.v2i2.31

Amalia, N., \& Chitra, A. (2018). The effect of application of rice dishwater and manure as organic fertilizer to the growth of mustard (Brassica juncea L.). Agroland: Agricultural Science Journal, 5(2), 74-82.

Amoro, I., Laura, M., Yolanda, M., \& Jose, L. A. (2019). Wastewater and leafy greens. Encyclopaedia for Food Security and Sustainability, 3, 385-389. https://doi.org/10.1016/B978-0-08-100596-5.22431-1

Andrianto, H. (2007). Pengaruh air cucian beras pada Adenium [Effect of washed rice water on Adenium] (Unpublished undergraduate thesis). Universitas Muhamadiyah Surakarta, Indonesia.

Ariwibowo, F. (2012). Pemanfaatan kulit telur ayam dan air cucian beras pada pertumbuhan tanaman tomat (Solanum lycopersicum) dengan media tanam hidroponik [Utilization of chicken eggshells and rice washed water on the growth of tomato plants (Solonum lycopercium L.) with hydroponic growing media] (Unpublished undergraduate thesis). Universitas Muhammadiah Surakarta, Indonesia.

Babu, P., Subhasree, R., Bhakyaraj, R., \& Vidhyalakshmi, R. (2009). Brown rice-beyond the color reviving a lost health food - A review. American-Eurasian Journal of Agronomy, 2(2), 67-72.

Bahar, A. (2016). Pengaruh pemberian limbah air cucian beras terhadap pertumbuhan tanaman kangkung darat (Ipomoea reptans Poir) [Effect of applying washed rice wastewater on the growth of land spinach (Ipomoea reptans Poir)]. Jurnal Ilmiah Mahasiswa Fakultas Pertanian, 3(2), 1-9. 
Balkhair, K. S., El-Nakhlawi, F. S., Ismail, S. M., \& Al-Solimani, S. G. (2013). Treated wastewater use and its effect on water conservation, vegetative yeild,yield components and water use efficiency of some vegetable crops grown under two different irrigation systems in western region, Saudi Arabia. European Scientific Journal, 9(21), 395-402. https://doi.org/10.19044/esj.2013.v9n21p\%p

Baning, C., Hafnati, R., \& Supriatno, S. (2016). Effect of red rice washed water application on vegetative growth of pepper plants (Piper nigrum L.). Jurnal Ilmiah Mahasiswa Pendidikan Biology, 1(1), 1-9.

Bee, Y. G. (2019). Food supply chain in Malaysia: Review of agricultural policies, public institutional setup and food regulations. Khazanah Research Institute. Retrieved Retrieved February 18, 2021, from http:// www.krinstitute.org/Discussion_Papers-@-Food_Supply_Chain_in_Malaysia-;_Review_of_Agricultural_ Policies,_Public_Institutional_Set-up_and_Food_Regulations.aspx

Blondine, C., \& Yuniarti, R. (2008). Peran serta masyarakat secara mandiri dalam melestarikan Bacillus thuringiensis H-14 galur lokal dalam buah kelapa untuk mengendalikan jentik Anopheles sp di Kampung Laut Kabupaten Cilacap [The role of the community to independently conserve local strains of Bacillus thuringiensis H-14 in coconut fruit to control Anopheles sp larvae in Kampung Laut, Cilacap Regency]. YARSI Medical Journal, 16(1), 033-038.

Brown, S., Kurtz, K., Bary, A., \& Cogger, C. (2011). Quantifying benefits associated with land application of organic residuals in Washington State. Environmental Science and Technology, 45(17), 7451-7458. https://doi.org/10.1021/es2010418

Bukhari (2013). The effect of organic fertilizer and rice washing water on growth and yield of eggplant (Solanum melongena L.). Jurnal Sains Riset, 3(1), 1-8.

Chandini, K. R., Kumar, R., \& Prakash, O. (2019). The impact of chemical fertilizers on our environment and ecosystem (2nd Ed.). Research Trends in Environmental Sciences.

Cirelli, G. L., Consoli, S., Licciardello, F., Aiello, R., Giuffrida, F., \& Leonardi, C. (2012). Treated municipal wastewater reuse in vegetable production. Agricultural Water Management, 104, 163-170. https://doi. org/10.1016/j.agwat.2011.12.011

Cogger, C. G. (2005). Potential compost benefits for restoration of soils disturbed by urban development. Compost Science and Utilization, 13(4), 243-251. https://doi.org/10.1080/1065657X.2005.10702248

Corcoran, E., Nellemann, C., Baker, E., Bos, R., Osborn, D., \& Savelli, H. (2010). Sick water? The central role of wastewater management in sustainable development. A rapid response assessment. UNEP/Earthprint.

Deepa, G., Singh, V., \& Naidu, K. A. (2008). Nutrient composition and physicochemical properties of Indian medicinal rice-Njavara. Food chemistry, 106(1), 165-171. https://doi.org/10.1016/j.foodchem.2007.05.062

Diana, R. Y. (2016). Gardening tips: Benefits of rice washing water for fertilizing plants. Retrieved May 3 , 2020, from https://mitalom.com/manfaat-air-cucian-beras-untuk-menyuburkan-tanaman/

Dini, I. R., \& Salbiah, D. (2019). Growth and pepper yields (Capsicum annuum L.) by giving a formulation of biological fertilizer of cellulolytic bacteria based on organic liquid waste. In Journal of Physics: Conference Series (Vol. 1351, No. 1, p. 012097). IOP Publishing.

Duaja, M. D., Arzita, \& Redo, Y. (2012). Growth analysis of Lettuce (Lactuca sativa L.) at different type of liquid organic fertilizer. Jurnal Program Studi Agroekoteknologi, 1(1), 33-41. 
Duncomb, D. R., Larson, W. E., Clapp, C. E., Dowdy, R. H., Linden, D. R., \& Johnson, W. K. (1982). Effect of liquid wastewater sludge application on crop yield and water quality. Journal of Water Pollution Control Federation, 54(8), 1185-1193.

FAO. (2015). World fertilizer trends and outlook to 2018. Food and Agriculture Organization of the United Nations Report. Retrieved February 17, 2021, from http://www.fao.org/3/i4324e/i4324e.pdf

Fitriani, C. L. (2019). Effect of spraying concentration of washed water of various types of rice on plant growth and yield of pak coy (Brassica rapa L.) (Diploma thesis). Universitas Andalas Padang, Indonesia. Retrieved May 3, 2020, from http://scholar.unand.ac.id/id/eprint/52640

Fitzpatrick, T. B., \& Chapman, L. M. (2020). The importance of thiamine (vitamin B1) in plant health: From crop yield to biofortification. Journal of Biological Chemistry, 295(34), 12002-12013. https://doi. org/10.1074/jbc.REV120.010918

Gatta, G., Libutti, A., Gagliardi, A., Beneduce, L., Brusetti, L., Borruso, L., Disciglio, G., \& Tarantino, E. (2015a). Treated agro-industrial wastewater irrigation of tomato crop: Effects on qualitative/quantitative characteristics of production and microbiological properties of the soil. Agricultural Water Management, 149, 33-43. https://doi.org/10.1016/j.agwat.2014.10.016

Gatta, G., Libutti, A., Gagliardi, A., Disciglio, G., Beneduce, L., d’Antuono, M., Rendina, M., \& Tarantino, E. (2015b). Effects of treated agro-industrial wastewater irrigation on tomato processing quality. Italian Journal of Agronomy, 10(632), 97-100. https://doi.org/10.4081/ija.2015.632

Ghafari, S., Hasan, M., \& Aroua, M. K. (2008). Bio-electrochemical removal of nitrate from water and wastewater - A review. Bioresource Technology, 99(10), 3965-3974. https://doi.org/10.1016/j. biortech.2007.05.026

Ginting, K. A., Dianita, R., \& Rahman A. (2017). Pengaruh pemberian nitrogen dan fosfor terhadap pertumbuhan legum Calopogonium mucunoides, Centrosema pubescens dan Arachis pintoi [The effect of nitrogen and phosphorous on the growth of Calopogonium mucunoides, Centrosema pubescens and Arachis pintoi] (Unpublished undergraduate thesis). Fakultas Peternakan Universitas Jambi. Retrieved April 28, 2020, from https://repository.unja.ac.id/id/eprint/849

GRiSP. (2013). Global Rice Science Partnership Rice almanac (4th Ed.). International Rice Research Institute.

Hairudin, R. (2015). Effectiveness of organic fertilizer rice washing water on the growth of mustard plants (Brassica juncea L.). Journal Perbal, 3(3), 79-84.

Handiyanto, S., Hastuti, U., \& Prabaningtyas, S. (2013, July 6). The effect of rice water washing medium on the speed of mycelium growth of white oyster mushrooms (Pleurotusostreatus var. Florida). In Seminar Nasional X Pendidikan Biologi FKIP UNS (pp. 1-6). Surakarta, Indonesia.

Hariyadi, S. P. (2020). The effect of watering on rice washing water, MSG water, and AC (Air Conditioner) wastewater on yields components and tomato yields (Lycopersicon esculentum L.) in the deep Peatland. Universal Journal, 7, 1-12.

Harrison, R. (2008). Composting and formation of humic substances. In Encyclopaedia of Ecology (pp. 713719). Academic Press. https://doi.org/10.1016/B978-008045405-4.00262-7 
He, Q., Feng, C., Chen, N., Zhang, D., Hou, T., Dai, J., Hao, C., \& Mao, B. (2019). Characterizations of dissolved organic matter and bacterial community structures in rice washing drainage (RWD)based synthetic groundwater denitrification. Chemosphere, 215, 142-152. https://doi.org/10.1016/j. chemosphere.2018.10.026

He, Q., Feng, C., Hu, Q., Li, R., \& Chen, N. (2016a). Biological denitrification using rice washing drainage (RWD) as carbon source for removing nitrate from groundwater. Desalination and Water Treatment, 57(46), 21990-21999. https://doi.org/10.1080/19443994.2015.1127780

He, Q., Feng, C., Peng, T., Chen, N., Hu, Q., \& Hao, C. (2016b). Denitrification of synthetic nitrate-contaminated groundwater combined with rice washing drainage treatment. Ecological Engineering, 95, 152-159. https://doi.org/10.1016/j.ecoleng.2016.06.043

Helmyati, S., Kiasaty, S., Amalia, A. W., Sholihah, H., Kurnia, M., Wigati, M., Rohana, A., Ishak, W. R. W., Hamid, N. A., Malik, V., \& Hu, F. (2020). Substituting white rice with brown and black rice as an alternative to prevent diabetes mellitus type 2: A case-study among young adults in Yogyakarta, Indonesia. Journal of Diabetes \& Metabolic Disorders, 19, 749-757. https://doi.org/10.1007/s40200-020-00555-8

Hernawan, E., \& Meylani, V. (2016). Physicochemical characteristics analysis of white rice, brown rice, and black rice (Oryza sativa L., Oryza nivara and Oryza sativa L. indica). Journal Kesehat Bakti Tunas Husada, 15(1), 79-91.

Hikmah, N. (2015). Pemanfaatan ekstrak kulit singkong dan air cucian beras pada pertumbuhan tanaman sirsak (Annona muricata L.) [Utilization of cassava peels extract and washed rice water on the growth of soursop (Annona muricata L.)] (Unpublished undergraduate thesis). Universitas Muhammadiyah Surakarta, Indonesia. Retrieved August 7, 2020, from http://eprints.ums.ac.id/33510/15/Naskah\%20Publikasi.pdf

Hoffland, E., Hakulinen, J., \& Van Pelt, J. A. (1996). Comparison of systemic resistance induced by a virulent and non-pathogenic pseudomonas species. Phytopathology, 86(7), 757-762.

Ibekwe, A., Gonzalez-Rubio, A., \& Suarez, D. (2018). Impact of treated wastewater for irrigation on soil microbial communities. Science of the Total Environment, 622, 1603-1610. https://doi.org/10.1016/j. scitotenv.2017.10.039

Iskarlia, G. R. (2017). The growth of hydroponic mustard plant (Brassica rapa L.) using the nutrition of washed rice water and chicken egg shells. Agric Sains Journal of Budidaya Tanaman Perkebunan Politeknik Hasnur, 3(2), 42-51.

Istiqomah, N. (2010). Influence of brown rice washing water application on growth and yield of celery (Apium graveolens L.) on Lebak's mashland. Agroscientiae, 3(17), 152-155.

Istiqomah, N. (2012). Efektivitas pemberian air cucian beras coklat terhadap produktivitas tanaman kacang hijau (Phaseolus radiatus L.) pada lahan rawa lebak [Effectiveness of applying washed brown rice water on the productivity of green bean (Phaseolus radiatus L.) on lowland swamps]. Ziraa'ah, 33(1), 99-108.

Itani, T., \& Ogawa, M. (2004). History and recent trends of red rice in Japan. Japan Journal of Crop Science, 73, $137-147$.

Jaramillo, M. F., \& Restrepo, I. (2017). Wastewater reuse in agriculture: A review about its limitations and benefits. Sustainability, 9(10), 1734-1753. https://doi.org/10.3390/su9101734 
Jones, D. L., \& Kielland, K. (2012). Amino acid, peptide and protein mineralization dynamics in a taiga forest soil. Soil Biology and Biochemistry, 55, 60-69. https://doi.org/10.1016/j.soilbio.2012.06.005

Juliano, B. O. (1985). Rice: Chemistry and technology (2nd Ed.). American Association of Cereal Chemists.

Juliano, B. O. (1993). Rice in human nutrition. FAO Food and Nutrition Series (26).

Juwarkar, A., Dutta, S., \& Pandey, R. (1988). Impact of domestic wastewaters on soil microbial populations. Water, Air, and Soil Pollution, 39(1-2), 169-177. https://doi.org/10.1007/BF00250956

Kalavrouziotis, I. (2015). The reuse of municipal wastewater in soils. Global Nest Journal, 17(3), 474-486. https://doi.org/10.30955/gnj.001625

Kalsum, U. S., Fatimah, \& Wasonowati, C. (2011). Effectiveness of washed rice water provision on growth and yield of white oyster mushroom (Pleurotus ostreatus). Journal of Agrovigor, 4(2), 86-92.

Kanchanawongkul, V. (2004). Performance comparison on materials surface of paddies hulling for rice- hulling machine. Engineering for Increasing Productivity, 13, 3-15.

Karlina, A., Yursida, \& Ruli, J. P. (2013). Growth response of water spinach (Ipomea reptans) to the application of liquid organic fertilizer from cow urine and organic fertilizer in tidal land overflow type C. Journal of Ilmiah Agriculture, 1, 1-16.

Khalid, S., Shahid, M., Bibi, I., Sarwar, T., Shah, A. H., \& Niazi, N. K. (2018). A review of environmental contamination and health risk assessment of wastewater use for crop irrigation with a focus on low and high-income countries. International Journal of Environmental Research and Public Health, 15(5), 895930. https://doi.org/10.3390/ijerph15050895

Khalid, S., Shahid, M., Dumat, C., Niazi, N. K., Bibi, I., Bakhat, H. F. S. G., Abbas, G., Murtaza, B., \& Javeed, H. M. R. (2017). Influence of groundwater and wastewater irrigation on lead accumulation in soil and vegetables: Implications for health risk assessment and phytoremediation. International Journal of Phytoremediation, 19(11), 1037-1046. https://doi.org/10.1080/15226514.2017.1319330

Kretschmer, N., Ribbe, L., \& Hartmut, G. (2002). Wastewater reuse for agriculture. Technology Resource Management \& Development-Scientific Contributions for Sustainable Development, 2, 37-64.

Leandro, M. (2009). Pengaruh konsentrasi air cucian beras terhadap pertumbuhan tanaman tomat dan terong [Effect of washed rice water concentrations on the growth of tomato and eggplant]. Retrieved May 26, 2021, from http://web.archive.org/web/20090731111508/http:/cikaciko.blogspot.com/2009/01/pengaruhkonsentrasi-air-cucian-beras.html

Lehmann, S. (2011). Resource recovery and materials flow in the city: Zero waste and sustainable consumption as paradigm in urban development. Journal of Green Building, 6(3), 88-105.

Lestari, B. K. (2010). Efektivitas penyiraman air leri dan ekstrak sari kedelai (Glycine max) terhadap pertumbuhan tanaman cabai hibrida (Capsicum annum L) [Effectiveness of watering with washed rice water and soybean extract on the growth of hybrid chili (Capsicum annum L.)] (Unpublished undergraduate thesis). Universitas Muhammadiyah Surakarta, Indonesia. Retrieved September 11, 2020, from http:// eprints.ums.ac.id/9784/ 
Li, W., \& Li, Z. (2009). In situ nutrient removal from aquaculture wastewater by aquatic vegetable Ipomoea aquatica on floating beds. Water Science and Technology, 59(10), 1937-1943. https://doi.org/10.2166/ wst.2009.191

Ling, W. H., Cheng, Q. X., Ma, J., \& Wang, T. (2001). Red and black rice decrease atherosclerotic plaque formation and increase antioxidant status in rabbits. The Journal of Nutrition, 131(5), 1421-1426. https:// doi.org/10.1093/jn/131.5.1421

Madaki, Y. S., \& Seng, L. (2013). Palm oil mill effluent (POME) from Malaysia palm oil mills: Waste or resource. International Journal of Science, Environment and Technology, 2(6), 1138-1155.

Malakar, M., \& Banerjee, S. (1959). Effect of cooking rice with different volumes of water on the loss of nutrients and on digestibility of rice in vitro. Food Research, 24, 751-756. https://doi.org/10.1111/j.1365-2621.1959. tb17330.x

Mechri, B., Mariem, F. B., Baham, M., Elhadj, S. B., \& Hammami, M. (2008). Change in soil properties and the soil microbial community following land spreading of olive mill wastewater affects olive trees key physiological parameters and the abundance of arbuscular mycorrhizal fungi. Soil Biology and Biochemistry, 40(1), 152-161. https://doi.org/10.1016/j.soilbio.2007.07.020

Moradi, A., Teh, C. B. S., Goh, K., Husni, M. A., \& Ishak, C. F. (2014). Decomposition and nutrient release temporal pattern of oil palm residues. Annals of Applied Biology, 164(2), 208-219. https://doi.org/10.1111/ aab.12094

Naidu, R., Megharaj, M., \& Owens, G. (2004). Recyclable urban and industrial waste-benefits and problems in agricultural use. In Managing soil quality: Challenges in modern agriculture (pp. 219-237). CAB International Oxfordshire.

Nooten, T. V., Diels, L., \& Bastiaens, L. (2008). Design of a multifunctional permeable reactive barrier for the treatment of landfill leachate contamination: Laboratory column evaluation. Environmental Science and Technology, 42(23), 8890-8895. https://doi.org/10.1021/es801704t

Nurhasanah, Y. S., Nelly, N., Reka, P., Anik, N., \& Muhammad, L. F. (2010). Potential waste water washing rice as a propagation media for plant probiotic bacteria. Institute Pertanian Bogor.

Nurhasanah. (2011). Rice washing water nutrient content. Pustaka Belaja.

Oliveira, A., \& Pampulha, M. E. (2006). Effects of long-term heavy metal contamination on soil microbial characteristics. Journal of Bioscience and Bioengineering, 102(3), 157-161. https://doi.org/10.1263/ jbb.102.157

Park, J. (2013). Environment and health: An overview of current trends at WHO and OECD. Journal of Environmental Health Sciences, 39(4), 299-311.

Pascual, C. D. S., Massaretto, I. L., Kawassaki, F., Barros, R. M. C., Noldin, J. A., \& Marquez, U. M. L. (2013). Effects of parboiling, storage and cooking on the levels of tocopherols, tocotrienols and $\gamma$-oryzanol in brown rice (Oryza sativa L.). Food Research International, 50(2), 676-681. https://doi.org/10.1016/j. foodres.2011.07.013

Patindol, J., Flowers, A., Kuo, M. I., Wang, Y. J., \& Gealy, D. (2006). Comparison of physicochemical properties and starch structure of red rice and cultivated rice. Journal of Agricultural and Food Chemistry, 54(7), 2712-2718. https://doi.org/10.1021/jf0523418 
Pescod, M. (1992). Wastewater treatment and use in agriculture. FAO Irrigation and Drainage.

Pimentel, D., \& Pimentel, M. H. (2007). Food, energy, and society. CRC press.

Purba, M. A., Fauzi, F., \& Sari, K. (2015). Pengaruh pemberian fosfat alam dan bahan organik pada tanah sulfat masam potensial terhadap P-tersedia tanah dan produksi padi (Oryza sativa L.) [Effect of applying natural phosphate and organic matter on potential acid sulfate soils on the available soil-P and rice production (Oryza sativa L.)]. Jurnal Agroekoteknologi Universitas Sumatera Utara, 3(3), 938-948.

Purnami, W. G., Yuswanti, N. H., \& Astiningsih, M. A. (2014). Effect of type and frequency of washed rice water on growth of orchid seeds (Phalaenopsis $s p$ ) after acclimatization. Jurnal of Agroekoteknologi Tropica, 3(1), 22-31.

Ratnadi, N. W. Y., Sumardika, N. Y., \& Setiawan, N. A. G. (2014). Effect of watering rice washing water and urea fertilizer with different concentrations on the growth of henna plants (Impatiens balsamina L.). Journal of Science Biological Education, 1(1), 1-9.

Razali, W. A. W., Baharuddin, A. S., Talib, A. T., Sulaiman, A., Naim, M. N., Hassan, M. A., \& Shirai, Y. (2012). Degradation of oil palm empty fruit bunches (OPEFB) fibre during composting process using in-vessel composter. BioResources, 7(4), 4786-4805.

Roy, P., Orikasa, T., Okadome, H., Nakamura, N., \& Shiina, T. (2011). Processing conditions, rice properties, health and environment. International Journal of Environmental Research and Public Health, 8(6), 19571976. https://doi.org/10.3390/ijerph8061957

Sadaf, J., Shah, G. A., Shahzad, K., Ali, N., Shahid, M., Ali, S., Hussain, R. A., Ahmed, Z. I., Traore, B., Ismail, I. M., \& Rashid, M. I. (2017). Improvements in wheat productivity and soil quality can accomplish by co-application of biochars and chemical fertilizers. Science of the Total Environment, 607, 715-724. https://doi.org/10.1016/j.scitotenv.2017.06.178

Sairi, F., Ismail, N., \& Ibrahim, N. (2018). The effect of FRAW towards the growth of chilli seedlings and its associated microorganisms. Malaysian Journal of Microbiology, 14(6), 606-610. https://doi.org/10.21161/ $\operatorname{mjm} .1461822$

Sakiah, \& Wahyuni, M. (2018). Analysis of c-organic, nitrogen, phosphorus and potassium in application areas and without application of palm oil mill effluent. Journal of Agriculture and Veterinary Science, 11(4), 23-27. https://doi.org/10.9790/2380-1104012327

Santos, C., Fonseca, J., Aires, A., Coutinho, J., \& Trindade, H. (2017). Effect of different rates of spent coffee grounds (SCG) on composting process, gaseous emissions and quality of end-product. Waste Management, 59, 37-47. https://doi.org/10.1016/j.wasman.2016.10.020

Schulz, R., \& Römheld, V. (1997). Recycling of municipal and industrial organic wastes in agriculture: benefits, limitations, and means of improvement. In Plant Nutrition for Sustainable Food Production and Environment (pp. 581-586). Springer. https://doi.org/10.1007/978-94-009-0047-9_184

Shamshuddin, J. (1989). Lime requirements of highly weathered Malaysian soils. Pertanika Journal of Tropical Agricultural Science, 12, 109-111.

Shaviv, A. (2001). Advances in controlled-release fertilizers. Advances in Agronomy, 71, 1-49. 
Siagian, A. S. (2018). Respon pemberian pupuk organik cair air cucian beras terhadap pertumbuhan dan produksi tanaman selada hijau (Lactuca satvia L.) [Response of organic fertilizer and washed rice water on the growth and production of lettuce (Lactuca sativa L.)] (Unpublished undergraduate thesis). Medan Area University, Indonesia. Retrieved May 26, 2021, from http://repository.uma.ac.id/handle/123456789/10578

Sianipar, O. P. (2004). Pengaruh frekuensi pemberian vitamin B1 dan konsentrasi pupuk $\mathrm{KNO}_{3}$ terhadap pertumbuhan vegetative bibit anggrek Dendrobium (Sakura white) [Effect of application frequency of vitamin B1 and KNO3 fertilizer concentration on the vegetative growth of Dendrobium orchid seeds (Sakura white)] (Unpublished undergraduate thesis). Fakultas Pertanian Universitas Udayana, Indonesia.

Sommers, L. (1977). Chemical composition of sewage sludges and analysis of their potential use as fertilizers. Journal of Environmental Quality, 6(2), 225-232. https://doi.org/10.2134/ jeq1977.00472425000600020026x

Sreenivasan, J., Govindan, M., Chinnasami, M., \& Kadiresu, I. (2012). Solid waste management in Malaysia - A move towards sustainability. Waste Management and Integrated Visions, 2005, 55-70.

Sullivan, D. M., Bary, A. I., Miller, R. O., \& Brewer, L. J. (2018). Interpreting compost analyses. Oregon State University Extension Service.

Sun, H., Terhonen, E., Koskinen, K., Paulin, L., Kasanen, R., \& Asiegbu, F. O. (2014). Bacterial diversity and community structure along different peat soils in boreal forest. Applied Soil Ecology, 74, 37-45. https:// doi.org/10.1016/j.apsoil.2013.09.010

Supraptiningsih, L. K., Nuriyanti, R., \& Sutrisno, A. (2019). Processing household waste (washed rice water) into liquid organic fertilizer in probolinggo regency empowering. Journal Pengabdian Masyarakat Fakulti Psikologi, 3, 12-20.

Suryana, H., Titiaryanti, M., \& Yuniasih, B. (2017). Effect of types and doses of waste on the growth of oil palm seedlings (pre nursery). Journal of Agromast, 2(1), 1-11.

Syuhaibah, S. A. (2017). Use of washed rice water as a fertilizer (Unpublished Undergraduate report). Universiti Putra Malaysia, Malaysia.

Teh, C. B. S. (2016). Availability, use, and removal of oil palm biomass in Indonesia. Report prepared for the International Council on Clean Transportation. Retrieved April 20, 2020, from https://theicct.org/ publications/availability-use-and-removal-oil-palm-biomass-indonesia

The Jakarta Post. (2017). Village in Bogor uses leftover rice water to grow plants. The Jakarta Post News Desk. Retrieved May 26, 2021, from https:/www.thejakartapost.com/news/2017/10/07/village-in-bogoruses-leftover-rice-water-to-grow-plants.html

Upadhyay, A., \& Karn, S. K. (2018). Brown rice: Nutritional composition and health benefits. Journal of Food Science and Technology Nepal, 10, 47-52. https://doi.org/10.3126/jfstn.v10i0.19711

Vermaat, J. E., \& Hanif, M. K. (1998). Performance of common duckweed species (Lemnoideae) and the waterfern Azolla filiculoides on different types of waste water. Water Research, 32(9), 2569-2576. https:// doi.org/10.1016/S0043-1354(98)00037-2 
Wardiah, L., \& Hafnati, L. R. (2014). Potensi limbah air cucian beras sebagai pupuk organik cair pada pertumbuhan pakchoy (Brassica rapa L.) [Potential of washed rice water as a liquid organic fertilizer on the growth of pakchoy (Brassica rapa L.)]. Jurnal Biologi Edukasi, 6(1), 34-38.

Watanabe, M., Ichinose, K., Sasano, K., Ozaki, Y., Tsuiki, T., Hidaka, H., \& Kanemoto, S. (2011). Effect of enzymatic treatment on sedimentation and flocculation abilities of solid particles in rice washing drainage and its relationship with protein profiles. Journal of Bioscience and Bioengineering, 112(1), 67-70. https:// doi.org/10.1016/j.jbiosc.2011.03.005

Watanabe, M., Makino, M., Kaku, N., Koyama, M., Nakamura, K., \& Sasano, K. (2013). Fermentative L-(+)lactic acid production from non-sterilized rice washing drainage containing rice bran by a newly isolated lactic acid bacteria without any additions of nutrients. Journal of Bioscience and Bioengineering, 115(4), 449-452. https://doi.org/10.1016/j.jbiosc.2012.11.001

Watanabe, M., Takahashi, M., Sasano, K., Kashiwamura, T., Ozaki, Y., Tsuiki, T., Hidaka, H., \& Kanemoto, S. (2009). Bioethanol production from rice washing drainage and rice bran. Journal of Bioscience and Bioengineering, 108(6), 524-526. https://doi.org/10.1016/j.jbiosc.2009.06.014

Wijiyanti, P., Hastuti, E. D., \& Haryanti, S. (2019). Effect of fertilizer fermentation period of rice wash water on green mustard plant growth (Brassica juncea L.). Buletin Anatomi dan Fisiologi, 4(1), 21-28.

Winance, G. M., Ernaningsih, D., \& Eting, D. E. (2018). Effect of utilization of rice washing water and eggshells on the growth of tomato plants (Lycopersium escuslentum Mill). BIOS Jurnal Pendidikan Biology dan Pengajaran, 1(1), 1-9.

Winpenny, J., Heinz, I., Koo-Oshima, S., Salgot, M., Collado, J., Hérnandez, F., \& Torricelli, R. (2013). Reutilización del Agua en Agricultura: ¿ Beneficios para Todos? [Water reuse in agriculture: Beneficial to all?].Food and Agriculture Organization.

World Count. (2020). Tons of waste from households. Retrieved February 18, 2020, from https://www. theworldcounts.com/challenges/planet-earth/waste/waste-from-households/story

Wulandari, C. G., Muhartini, S., \& Trisnowati, S. (2012). Pengaruh air cucian beras merah dan beras putih terhadap pertumbuhan dan hasil selada (Lactuca sativa L.) [Effect of washed brown and white rice water on the growth and yield of lettuce (Lactuca sativa L.)]. Vegetalika, 1(2), 24-35. https://doi.org/10.22146/ veg. 1516

WWDR. (2016). The United Nations world water development report. United Nations Educational, Scientific and Cultural Organization.

Yulianingsih, R. (2017). Pengaruh air cucian beras terhadap pertumbuhan dan hasil terung ungu (Solanum melongena L.). [Effect of rice washing water on growth and yield of superior eggplant (Solanum Melongea L.)]. Publikasi Informasi Pertanian, 13(24), 61-68.

Zou, J., Guo, X., Han, Y., Liu, J., \& Liang, H. (2012). Study of a novel vertical flow constructed wetland system with drop aeration for rural wastewater treatment. Water, Air, and Soil Pollution, 223(2), 889-900. https://doi.org/10.1007/s11270-011-0910-x 
